\title{
Sistem Pendukung Keputusan Seleksi Atlet Panahan menggunakan Logic Fuzzy metode AHP-TOPSIS
}

\author{
Tutus Praningki ${ }^{1}$, Muhaji Bayu², Agus Pramono \\ ${ }^{1,2,3}$ Sekolah Tinggi Teknologi Cahaya Surya Kediri \\ Email:tutuspraningki_stt@cahayasurya.ac.id,muhajibayu_stt@cahayasurya.ac.id,aguspramono_stt@cahayasurya.ac.id
}

\begin{abstract}
Abstrak
Panahan adalah cabang olahraga di induk organisasi PERPANI. Pelatihan yang dibentuk guna mencitakan atlet panaha terbaik dalam perkembangannya selalu berudaha mengikuti kejuaraan dengan langkah pelatihan atlet panahan secara teratur. Proses seleksi atlet pada PERPANI dinilai masih manual dan belum terperinci. Dalam penilaian yang bersifat subjektif (berdasarkan kepentingan pribadi), dapat menimbulkan kecemburuan pada proses penyeleksian seorang atlet. Diperlukan sebuah sistem guna membantu solusi tersebut, sistem dengan Logic Fuzzy metode AHP-TOPSIS dipilih untuk menyeleksi atlet panahan. Penulis menggunakan 6 kriteria dan 24 subkriteria dalam sistem. Proses penentuan bobot kriteria menggunakan Logic Fuzzy pada perhitungannya. Penelitian ini menggunakan Bahasa perograman PHP dan menggunakan MySQL sebagai basisdatanya. Penelitian ini berhasil memberikan hasil sistem pendukung keputusan menggunakan Logic Fuzzy metode AHP-TOPSIS mampu mengatasi permasalah dalam melakukan seleksi atlet panahan.
\end{abstract}

Kata Kunci: MySQL, Seleksi Atlet Panahan, PHP, Logic Fuzzy, AHP-TOPSIS

\section{Pendahuluan}

\subsection{Latar Belakang}

Perkembangan teknologi informasi yang semakin maju salah satunya dalam dalam memberikan solusi terbaik disetiap permasalahan yang ada membutuhkan kemampuan computer. Sebuah sistem pendukung keputusan berbasis komputer (Computer Based Decision Support System) dirancang untuk memudahkan pengambilan keputusan dalam memecahkan permasalahan yang dihadapi. Setiap permasalahan diperlukan cara yang tepat dan mampu memecahkan masalah tersebut dengan langkah paling manjur, efektif dan efisien untuk pemenuhan kebutuhannya.

Dalam menggelorakan momentum semangat berolahraga memerlukan perencanaan, kerja keras, komitmen, dan tentunya latihan sehingga dalam arena kompetisi yang ketet diselenggarakan menghasilkan kesuksesan yang berimbang. Sukses atlet dalam hal ini diperlukan rancangan dengan baik aktifitas latihan fisik, salah satu bentuk program latihan dirancang dengan tahapan-tahapan dalam kurun waktu yang panjang. Program latihan haruslah dimulai dari anak-anak dalam setiap cabang olahraga sehingga dapat dikembangkan secara terus menerus. Prinsip-prinsip latihan perlu dikaji ulang pada keilmuan, perkembangan anak, sikap anak dan nutrisi agar prestasi puncak dapat sesuai rencana pada proses program latihan.

Performa atlet di Indonesia yang di paparkan oleh beberapa ahli olahraga menyimpulkan bahwa semakin terperosot dalam kompetisi yang disebabkan oleh factor-faktor yang tidak konsisten sebagai pedoman dalam bidang-bidang ini. Pemanah harus memiliki kesabaran, ketekunan, konsentrasi dan daya tahan mental yang tinggi, sehingga unsur-unsur seperti bentuk tubuh, teknik dasar, mekanisme gerak, mentalitas dan kondisi fisik secara keseluruhan yang harus dimiliki oleh 
seorang atlet panahan dapat dibentuk. Dalam menguasai suatu teknik yang baik dicabang olahraga panahan tidaklah mudah, dimana dalam penguasaannya tersebut bisa didapat melalui proses latihan yang berkesinambungan.

Diperlukan rancang bangun sistem pendukung keputusan yang dapat digunakan oleh penyelenggara seleksi secara terbuka yang dapat membantu menyeleksi atlet untuk mendapatkan atlet yang paling potensial guna mencapai potensi yang maksimal. Sistem pendukung keputusan AHP-TOPSIS telah dipakai oleh penelitian terdahulu untuk menentukan penelusuran minat dan bakat (PMDK) jalur penerimaan mahasiswa baru di perguruan tinggi. Metode AHP dianggap mampu menguraikan masalah menjadi suatu hirarki sehingga mudah dalam penyelesaiannya. Sedangkan dalam penelitian yang menggunakan metode TOPSIS merupakan metode perangkingan yang memiliki kelebihan yakni menganggap solusi terbaik tidak hanya solusi yang paling mendekati solusi ideal tapi juga yang paling jauh dari solusi negatif. Namun, metode AHP dalam pembobotan terdapat kelemahan, yakni dianggap masih kurang memiliki nilai subjektifitas yang tinggi. Untuk mengulangi hal tersebut pembobotan kriteria metode AHP akan di kombinasikan dengan Fuzzy. Kombinasi metode Fuzzy dan AHP memiliki subtifitas yag lebih supaya atlet yang terpilih lebih dari satu.

Meninjau dari permasalahn yang dijelaskan penulis diatas dibuatkan tugas akhir dengan judul "Sistem Pendukung Keputusan Seleksi Atlet Panahan menggunakan Logic Fuzzy metode AHP-T OPSIS". Diharapkan dengan menggunakan bobot kriteria dari penilaian uji dalam input penilaian. Sistem ini dapat lebih diterima oleh kalangan pengguna.

\subsection{Rumusan Masalah}

Mengacu pada permasalahan diatas dibuat rumusan masalah yang akan diselesaikan dalam penelitian ini adalah :

a. Bagaimana membangun sebuah sistem pendukung keputusan Seleksi Atlet Panahan menggunakan Logic Fuzzy metode AHP-TOPSIS?

b. Bagaimana sistem ini dapat menentukan Seleksi Atlet Panahan menggunakan Logic Fuzzy metode AHP-TOPSIS?

\subsection{Batasan Masalah}

Batasan masalah dari uraian di atas adalah:

a. Sistem pendukung keputusan ini hanya di gunakan untuk pengambilan keputusan seleksi atlet panahan pada study kasus di PERPANI Kota Kediri.

b. Sistem pendukung keputusan ini hanya didasarkan pada prosedur-prosedur seleksi atlet pada umumnya.

c. Kriterian dan subkriteria atlet panahan hanya didapat dari studi lieratur bukan dengan penelitian sendiri.

d. Keluaran sistem pendukung keputusan ini adalah nilai preferensi/nilai akhir yang menjadi acuan dalam keputusan seleksi.

e. Perancangan aplikasi dibuat dengan Bahasa Pemrograman PHP, HTML, CSS, XAMPP dengan database menggunakan MySQL.

\subsection{Tujuan Penelitian}

Tujuan dalam rencana pembuatan sistem pendukung keputusan guru berprestasi ini adalah :

a. Terbentuknya sistem pendukung keputusan Seleksi Atlet Panahan menggunakan Logic Fuzzy metode AHP-TOPSIS.

b. Terimplementasinya sistem penentuan Seleksi Atlet Panahan dalam menentukan Atlet Panahan berprestasi. 


\subsection{Manfaat Penelitian}

Dalam penilitian ini dihasilkan manfaat sebagai berikut :

a. Bagi peneliti dan akademisi:

Menambah wawasan tentang teori yang diambil oleh peniliti dan Mengenal Langkah pemilihan Seleksi atlet panahan dengan metode Fuzzy yang di bahas oleh penulis.

b. Bagi pelatih/pihak seleksi:

Membantu instrument dalam pengukuran seleksi pada penjaringan atlet panahan yang potensial.

\section{Landasan Teori}

\subsection{Tinjauan Pustaka}

Berikut tinjauan pustaka terdahulu adalah teori-teori terdahulu yang dipakai oleh peneliti sedang landasan dasar teori adalah teori-teori penelitian untuk menjawab problematika masalah. Beberapa hasil penelitian-penelitian sebelumnya, antara lain: Insan Afifah, (2018) membuat penelitian dengan judul "Sistem pendukung keputusan rekomendasi kenaikan jabatan dosen UIN maulana Malik Ibrahim Malang menggunakan Fuzzy AHP”. Sistem pendukung keputusan dengan menerapkan perangkingan pada penelitian. Pemeringkatan ini digunakan untuk menentukan tingkat kepentingan setiap kriteria dan dalam menentukan rekomendasi peringkat untuk promosi dosen menggunakan metode Fuzzy Analytical Hierarchy Process (Fuzzy AHP). Tahap perhitungan dalam metode Fuzzy AHP dimulai dengan nilai penting dari setiap kriteria, setelah itu nilai penting untuk setiap alternatif yang kemudian dihasilkan dari kepentingan kriteria dan kepentingan alternatif dikalikan dengan menghasilkan rekomendasi. Dalam penelitian ini, data diambil dari staf UIN Maliki Malang. Dari akurasi yang di teliti menghasilkan kesimpulan bahwa sistem dapat mendukung pengambilan keputusan untuk upaya rekomendasi usaha yang lebih baik menggunakan metode Fuzzy AHP.

Pada penelitian yang dipaparkan oleh Husnul Hakim dkk, (2018). Dalam sebuah penelitian yang menggambarkan desain sistem pengambilan keputusan "Seleksi penelusuran minat dan kemampuan (PMDK) dengan Fuzzy TOPSIS". Dalam penelitian ini, akan dikembangkan teknik Fuzzy Technique for Order Preference by Similarity to Ideal Solution (Fuzzy TOPSIS) yang menjelaskan kriteria seleksi siswa yang melibatkan banyak kriteria. Menggunakan tiga parameter yang menentukan penerimaan calon siswa dengan menggunakan metode Fuzzy TOPSIS. Digunakan tiga kriteria untuk seleksi PMDK pada penelitian ini, yaitu nilai raport, kualitas sekolah, dan nilai histori alumni. Ketiga kategori parameter tersebut diberi bobot yang dipresentasikan dengan fuzzy number.

Ketiga kategori tersebut dapat diberi bobot cukup penting, penting, dan sangat penting. Berdasarkan hasil wawancara, bobot kriteria rapor adalah penting, bobot kualitas sekolah adalah penting, dan bobot histori alumni adalah sangat penting. Hasil pengujian menunjukan bahwa ada kolerasi closeness coefficient sebesar 0,48 dengan parameter tersebut, kelemahan dalam penelitian ini kurangnya batas minimal yang dijadikan patokan. Padahal batas minimal closeness coefficient 0.4 agar kelak siswa dapat memperoleh nilai minimal IPK 3,00, jadi semua mahasiswa yang mendaftar diterima.

Menurut Mukhtar,(2017) penelitian yang berjudul "Hubungan Tingkat Konsentrasi dengan Ketepatan Memanah pada Atlet panahan Aceh Archery School Binaan Dispora Kabupaten Bireuen". Panahan adalah olahraga yang mengedepankan kombinasi dari gerak seni dan ketahanan mental untuk mendapatkan skor tertinggi. Kemampuan untuk fokus pada tugas dengan tidak tergaggu dan tidak terpengaruh oleh rangasangan yang bersifat internal dan eksternal merupakan definisi dari konsentrasi. Dalam penelitian ini bertujuan untuk mengetahui hubungan konsentrasi dan ketetapan panahan pada atlet panahan untuk menentukan sampel penelitian dan menggunakan analisis kolerasi sederhana. Hasil pengolahan dan analisis data menyimpulkan hubungan yang signifikan antara tingkat konsentrasi dengan atlet panahan presisi pada tingkat klasifikasi dengan nilai rata-rata memuaskan. 
Meninjau dari alasan tersebut, perlu dibuatkan sebuah sistem yang dapat mendukung suatu keputusan yang dapat digunakan oleh pelatih maupun penyelenggara seleksi secara terbuka untuk dapat membantu dalam menyeleksi atlet guna mendapatkan atlet yang potensial dalam mencapai prestasi yang maksimal. Dalam membangun sistem keputusan pada penelitian ini menggunakan metode Analytical Hierarchy Process - Technique for Order Preference by Similarity to Ideal Solution (AHP-TOPSIS). Metode AHP dianggap mampu menguraikan masalah menjadi suatu hirarki sehingga mudah dalam penyelesaiannya. Sedangkan metode TOPSIS merupakan metode perangkingan yang memiliki kelebihan yakni menganggap solusi terbaik tidak hanya solusi yang paling mendekati solusi ideal,tetapi juga yang paling jauh dari solusi negatif. Namun, metode AHP dalam pembobotan terdapat kelemahan, yakni dianggap masih memiliki nilai subjektifitas yang tinggi. Untuk menanggulangi hal tersebut, pembobotan kriteria metode AHP akan dikombinasikan dengan metode Fuzzy. penelitian tersebut belum menerapkan metode Fuzzy AHP digabungkan dengan TOPSIS. Dengan penelitian ini penulis mencoba menggabungkan metode AHP dengan TOPSIS sehingga nanti dapat membantu dalam penelitian. Dengan begitu, penulis mengambil judul "Sistem Pendukung Keputusan Seleksi Atlet Panahan menggunakan Logic Fuzzy metode AHP-TOPSIS".

\subsection{Sistem Pendukung Keputusan (SPK)}

Adalah sistem yang mendukung kegiatan pengambil keputusan dari sebuah informasi untuk memecahkan suatu masalah dan mempertimbangkan keputusan yang dibuat. Beberapa pengertian sistem pendukung keputusan menurut para ahli. Dalam penelitian yang di teliti Turban (2005), SPK didefinisikan kemampuan sebuah sistem dalam memecahkan masalah dan kemampuan dalam kondisi semi terstruktur maupun terstruktur untuk pengkomunikasian sebuah permasalahan, dimana tak seorangpun tahu secara pasti bagaimana keputusan seharusnya dibuat. Karakteristik dari sistem pendukung keputusan yang membedakan dari sistem informasi yang lain (Kusrini, 2007) adalah:

a. SPK dirancang untuk membantu pengambil keputusan dalam memecahkan masalah yang sifatnya semi terstruktur ataupun tidak terstruktur dengan penggunaan model-model analisis data konvensional yang terintegrasi informasi.

b. SPK dirancang sedemikian rupa sehingga dapat digunakan atau dioperasikan dengan mudah oleh orang-orang yang tidak memiliki kemampuan dasar mengoperasikan komputer.

c. SPK dirancang dengan menekankan pada aspek fleksibilitas serta kemampuan adaptasi yang tinggi, sehingga mudah disesuaikan dengan berbagai perubahan lingkungan yang terjadi dan dapat digunakan sesuai kebutuhan pemakai.

\subsection{Pengertian AHP (Analytic Hierarchy Process)}

Analytic Hierarchy Process (AHP) dikembangkan oleh Thomas L. Saaty (Saaty, 1977),(Saaty, 1980), (Saaty,1990) yang diekspos oleh (Insan Afifah, 2018). Ini adalah metode pengambilan keputusan multi kriteria yang memungkinkan penilaian relatif dan prioritas alternatif. Dalam teorinya AHP memungkinkan untuk mengintegrasikan aspek kuantitatif dan kualitatif pengambilan keputusan, yang menjadikannya metode yang efisien dan efektif dalam konteks yang kompleks. AHP didasarkan pada penggunaan perbandingan berpasangan. Yang mengarah pada penjabaran skala rasio. AHP menggunakan model hirarki untuk masalah keputusan, yang terdiri dari tujuan keseluruhan, sekelompok alternatif dan sekelompok kriteria yang menghubungkan alternatif ke tujuan (goal).

Perbandingan berpasangan secara klasik dilakukan dengan menanyakan seberapa bernilai alternatif $\mathrm{A}$ dibandingkan kriteria $\mathrm{C}$ dibandingkan pula alternatif $\mathrm{B}$ dan lainnya. Perbandingan berpasangan merupakan matriks kuadrat dalam peritungan akhir, nilainya antara 1/9 dan 9. Elemen-elemen diagonal dari matriks sama dengan 1 sedangkan yang lain memverifikasi dua kondisi tertentu.

Sebuah informasi diproses secara matematis, untuk mengubah informasi pengguna, objektif atau subjektif, menjadi informasi matematis. Prioritas kemudian ditentukan berkat matriks dan 
uji konsistensi yang dapat dilakukan untuk mengevaluasi koherensi penilaian dari pengguna. Hasil akhir adalah bobot untuk setiap alternatif mengenai kriteria sintesis dari struktur hirarki. Dalam metode AHP dilakukan langkah-langkah sebagai berikut:

a. Mendefinisikan masalah dan menentukan solusi yang diingingkan.

b. Membuat struktur hirarki yang diawali dengan tujuan utama.

c. Menentukan matriks perbandingan berpasangan

d. Menentukan perbandingan berpasangan, yaitu membandingkan kriteria berpasangan sesuai dengan kriteria yang diberikan.

e. Menghitung nilai eigen vector (vektor prioritas) dan menguji konsistensinya.

f. Untuk seluruh tingkat hirarki dihitung nilainya sampai menghsilkan pada proses menguji konsistensinya. .

g. Menghitung vektor eigen (vektor prioritas) dari setiap matriks perbandingan berpasangan yang merupakan bobot setiap elemen untuk penentuan prioritas elemen-elemen pada tingkat hirarki terendah sampai mencapai tujuan.

h. Memeriksa konsistensi hirarki.

\subsection{Fuzzy Analytic Hierarchy Process (F-AHP)}

Langkah pertama dan langkah akhir dari AHP adalah prosedur yang relatif sederhana dan standard, sedangkan penilaian prioritas berdasarkan perbandingan berpasangan membutuhkan beberapa metode prioritas yang harus diterapkan. Namun pendekatan prioritas nilai eight vector AHP tidak dapat digunakan sebagai acuan. Kerika pembuat keputusan menghadapi masalah yang kompleks dan tidak pasti dan menyatakan nilai perbandingannya sebagai rasio tidak pasti seperti sekitar dua kali lebih penting, dimaknai antara dua dan empat kali kurang penting, dll. Cara alami untuk mengatasi penilaian tersebut yang tidak pasti adalah dengan mengekspresikan rasio perbandignan sebagai himpunan kekaburan atau bilangan Fuzzy, yang menggabungkan ketidakjelasan pemikiran manusia. Ketika membandingkan dua elemen pada tingkat hirarki keputusan yang sama, penilaian perbandingan yang tidak pasti dapat diwakilkan oleh angka Fuzzy.

Untuk menentukan derajat kepentingan perbandingan pada Metode Fuzzy AHP, digunakan aturan fungsi dalam bentuk bilangan fuzzy segitiga atau Triangular Fuzzy Number (TFN) yang disusun berdasarkan himpunan linguistik (Afrianty, 2011). Inti dari fuzzy AHP terletak pada perbandingan berpasangan yang digambarkan dengan skala rasio yang berhubungan dengan skala fuzzy. TFN dapat menunjukkan kesubyektifan perbandingan berpasangan atau dapat menunjukkan derajat yang pasti dari ketidakpastian (kekaburan). Skala perbandingan tingkat kepentingan fuzzy dijelaskan sebagai berikut (Chang, 1996):

Tabel 2.1 Skala Perbandingan Tingkat Kepentingan TFN

\begin{tabular}{|c|c|c|c|}
\hline $\begin{array}{c}\text { Intensitas } \\
\text { Kepentingan } \\
\text { AHP }\end{array}$ & $\begin{array}{l}\text { Himpunan } \\
\text { Linguistik }\end{array}$ & $\begin{array}{c}\text { Triangular } \\
\text { Fuzzy } \\
\text { Number } \\
\text { (TFN) }\end{array}$ & $\begin{array}{c}\text { Reciprocal } \\
\text { (Kebalikan) }\end{array}$ \\
\hline 1 & $\begin{array}{l}\text { Perbandingan } \\
\text { elemen yang } \\
\text { sama }\end{array}$ & $(1,1,1)$ & $(1,1,1)$ \\
\hline 2 & Pertengahan & $(1,2,4)$ & $\left(\frac{1}{4}, \frac{1}{2}, \frac{1}{1}\right)$ \\
\hline 3 & $\begin{array}{l}\text { Elemen satu } \\
\text { cukup pent- } \\
\text { ing dari yang } \\
\text { lain }\end{array}$ & $(1,3,5)$ & $\left(\frac{1}{5}, \frac{1}{3}, \frac{1}{1}\right)$ \\
\hline 4 & $\begin{array}{l}\text { Pertengahan } \\
\text { elemen satu } \\
\text { lebih cukup } \\
\text { penting dari } \\
\text { yang lainnya }\end{array}$ & $(2,4,6)$ & $\left(\frac{1}{6}, \frac{1}{4}, \frac{1}{2}\right)$ \\
\hline 5 & $\begin{array}{l}\text { Elemen satu } \\
\text { kuat pent- } \\
\text { ingnya dari } \\
\text { yang lain }\end{array}$ & $(3,5,7)$ & $\left(\frac{1}{7}, \frac{1}{5}, \frac{1}{3}\right)$ \\
\hline 6 & Pertengahan & $(4,6,8)$ & $\left(\frac{1}{8}, \frac{1}{6}, \frac{1}{4}\right)$ \\
\hline
\end{tabular}




\begin{tabular}{|c|l|c|c|}
\hline 7 & $\begin{array}{l}\text { Elemen satu } \\
\text { lebih kuat } \\
\text { pentingnya } \\
\text { dari yang lain }\end{array}$ & $(5,7,9)$ & $\left(\frac{1}{9}, \frac{1}{7}, \frac{1}{5}\right)$ \\
\hline 8 & Pertengahan & $(6,8,9)$ & $\left(\frac{1}{9}, \frac{1}{8}, \frac{1}{6}\right)$ \\
\hline 9 & $\begin{array}{l}\text { Elemen satu } \\
\text { mutlak lebih } \\
\text { penting dari } \\
\text { yang lainnya }\end{array}$ & $(7,9,9)$ & $\left(\frac{1}{9}, \frac{1}{9}, \frac{1}{7}\right)$ \\
\hline
\end{tabular}

Adapun metode yang digunakan penulis untuk mengembangkan pada sistem ini adalah Fuzzy AHP, yang memiliki tahapan-tahapan sebagai berikut:

a. Menentukan nilai sintesis fuzzy $(\mathrm{Si})$ prioritas dengan rumus:

$$
\begin{aligned}
& S_{i}=\sum_{j=1}^{m} M_{g i}^{j} \otimes\left[\sum_{i=1}^{n} \sum_{j=1}^{m} M_{g i}^{i}\right]^{-1} \\
& \begin{array}{ll}
\sum_{j=1}^{m} M_{g i}^{j} & =\text { menjumlahkan nilai sel pada kolom yang dimulai dari kolom } 1 \text { di setiap baris } \\
\text { matriks. }
\end{array}
\end{aligned}
$$

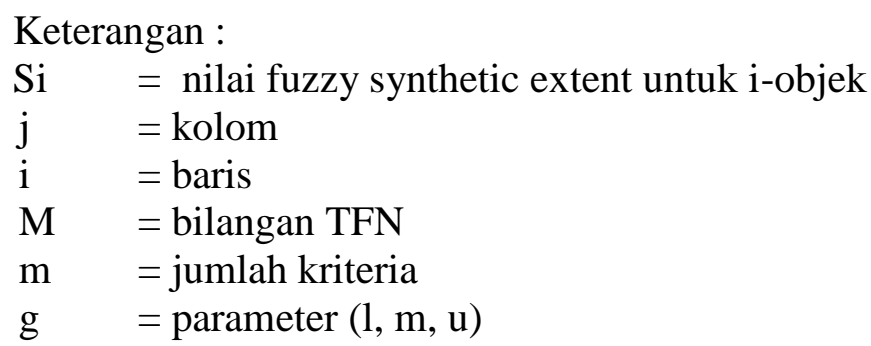

b. Perbandingan tingkat kemungkinan antara bilangan fuzzy. Digunakan untuk nilai bobot pada masing-masing kriteria. Untuk 2 bilangan TFN M1 = (11, m1, u1) dan $\mathrm{M} 2=(12, \mathrm{~m} 2, \mathrm{u} 2)$, dengan tingkat kemungkinan $\mathrm{M} 1 \geq \mathrm{M} 2$ didefinisikan sebagai berikut:

$$
\boldsymbol{V}\left(M_{1} \geq M_{2}\right)=\sup \left[\min \left(\mu M_{1}(x), \mu M_{2}(y)\right)\right], y \geq x
$$

Tingkat kemungkinan untuk bilangan fuzzy konveks dapat diperoleh dengan persamaan berikut:

$$
V\left(M_{2} \geq M_{1}\right)=\left\{\begin{array}{c}
1 ; j \text { ika } m_{2} \geq m_{1} \\
0 ; j \text { ika } l_{2} \geq u_{1} \\
\frac{l_{1}-u_{2}}{\left(m_{2}-u_{2}\right)-\left(m_{1}-l_{1}\right)} ; \text { untuk kandisi lainnya }
\end{array}\right.
$$

c. Jika hasil nilai fuzzy lebih besar dari nilai $\mathrm{k}$ fuzzy, Mi , dimana $\mathrm{i}=1,2, \ldots, \mathrm{k}$, yang dapat ditentukan dengan menggunakan operasi max dan min sebagai berikut:

Diasumsikan bahwa:

$$
d^{\prime}\left(A_{1}\right)=\operatorname{minV}\left(S_{i} \geq S_{k}\right) \text { untuk } k=1,2, \ldots, n ; k \neq i
$$

Maka nilai vektor bobot didefinisikan sebaai berikut:

$$
W^{\prime}=\left(d^{\prime}\left(A_{1}\right), d^{\prime}\left(A_{2}\right), \ldots, d^{\prime}\left(A_{n}\right)\right)
$$

d. Normalisasi nilai vektor atau nilai prioritas kriteria yang telah diperoleh, perumusan normalisasinya adalah :

$$
W=\left(d\left(A_{1}\right), d\left(A_{2}\right), \ldots, d\left(A_{n}\right)\right)^{T}
$$

Dimana W adalah hasil akhir bobot kriteria.

\subsection{Technique Order Preference by Similarity to Ideal Solution (TOPSIS)}

TOPSIS menerapkan konsep beberapa kriteria untuk mengidentifikasi solusi dari serangkaian alternatif yang terbatas berdasarkan minimalisasi jarak solusi secara ideal dan maksimalisasi jarak dari titik ordinat. Juga merupakan salah satu pendekatan MCDM klasik, berdasar- 
kan fungsi agregasi untuk menemukan solusi ideal positif dan terjauh dari solusi ideal negatif, namun tidak mempertimbangkan relatif dari jarak. Keuntungan relative dari TOPSIS adalah kemampuan untuk mengidentifikasi alternatif terbaik dengan cepat, metode normalisasi untuk TOPSIS dapat disederhanakan sebagai transformasi linier. Perhitungan TOPSIS meliputi prosedurprosedur sebagai berikut:

a. Menetapkan matriks keputusan untuk peringkat

Setiap normalisasi dari nilai Rij dapat dilakukan dengan perhitungan sebagai berikut:

$$
R_{i j}=\frac{x_{i j}}{\sqrt{\sum_{i=1}^{m} x_{i j}^{2}}}
$$

Selanjutnya pembobotan pada matriks yang telah dinormalisasikan.

Rumus matriks ternormalisasi yang terbobot :

$$
y_{i j}=w_{i} r_{i j}
$$

b. Menghitung matriks keputusan ternormalisasi yang terbobot weighted normalized matrix V dapat dihasilkan :

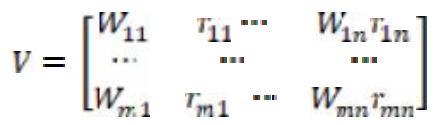

c. Menghitung matriks solusi ideal positif dan matriks solusi ideal negative. Untuk solusi ideal positif dinotasikan dengan A+ dan solusi ideal negatif dinotasikan dengan A-, sebagai berikut:

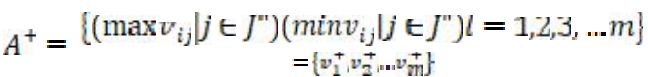

$$
\begin{aligned}
& A=\left\{\left(\max _{i j} \mid j \in J^{\prime \prime}\right)\left(\operatorname{minv}_{i j} \mid j \in J^{\prime \prime}\right) \ell=1,2,3, \ldots m\right\}
\end{aligned}
$$

d. Menghitung jarak antara nilai setiap alternatif dengan matriks solusi ideal positif dan matriks solusi ideal negative, Jarak nilai alternatif untuk solusi ideal positif.

$$
d_{i}^{+}=\sqrt{\sum_{j=1}^{n}\left(y_{j}^{+}-y_{i j}\right)^{2}}
$$

Jarak nilai altrnatif untuk solusi ideal negatif

$$
d_{i}^{-}=\sqrt{\sum_{j=1}^{n}\left(y_{i j}-y_{j}^{-}\right)^{2}}
$$

e. Menghitung nilai preferensi untuk setiap alternatif

$$
c_{i}=\frac{d_{i}^{-}}{d_{i}^{-}+d_{i}^{+}}
$$

dengan $0<\mathrm{Ci}<1$ dan $\mathrm{i}=1,2,3, \ldots \mathrm{m}$ 


\section{Perancangan Sistem}

Pada penelitian ini menggunakan sebuah sistem pendukung keputusan memakai metode kuantatif dengan logic fuzzy metode AHP-TOPSIS. Menurut Sugiyono (2010), metode kuantitatif adalah jenis data yang diukur atau dapat dihitung secara langsung, sedangkan informasi atau penjelasannya dinyatakan dengan angka atau bentuk bilangan. Menjelaskan metode penelitian ini merupakan penelitian yang berlandaskan para filsafat, mekanisme yang digunakan untuk meneliti pada populasi atau sampel tertentu, pada umumnya pengambilan sampel dilakukan secara teracak, dan pengumpulan data menggunakan instrumen penelitian dengan menggunakan analisis data kuantitatif berdasarkan kriteria yang telah ditentukan oleh pelatih dengan tujuan untuk menguji hipotesis yang telah ditetapkan. Dalam tugas akhir ini populasinya ada semua atlet panahan di kota kediri, sedangkan sampelnya 5 orang yang diambil secara random.

Tahap-tahap yang dilakukan dalam tugas akhir ini adalah metode penumpulan data, metode analisis data dan kebutuhan sistem dan implementasi. Metode pengumpulan data untuk sistem pendukung keputusan Seleksi Atlet Panahan menggunakan Logic Fuzzy metode AHPTOPSIS antara lain Observasi dan studi literatur.

a. Observasi ( Riset Awal )

Metode pengumpulan data dan riset awal yang melakukan pengamatan atau peninjauan langsung pada saat pengambilan data di PERPANI Kota Kediri, untuk mencari data-data yang dibutuhkan sesuai dengan permasalahan. Riset awal dilakukan dengan obsevasi/pengamatan untuk meyakinkan bahwa judul ini memang diperlukan. Pada bagian Analisa, peneliti mengobservasi dan mengambil kriteria serta data data untuk membuat sistem pendukung keputusan.

b. Studi Literatur

Pada tahap ini penulis menggali melalui konsep penelitian kepustakaan berdasarkan studi yang telah dilakukan sebelumnya untuk digunakan sebagai studi pendukung pada topik penelitian oleh penulis.

Tahap-tahap yang dilakukan pada metode analisis data dan perancangan sistem dalam tugas akhir ini adalah akuisi data dan penentuan kriteria dan pembobotan. Akuisi data merupakan sistem yang berguna untuk mengumpulkan dan menyiapkan data, penulis memaparkan menggunakan dua referensi data dalam penelitian yang di ambil berupa data primer dan data sekunder.

\subsection{Analisis Data}

Kebutuhan sistem yang dapat membantu pengguna dalam hal ini pelatih maupun panitia penyelenggara seleksi atlet panahan dengan sistem seleksi uji tanding dan non-tanding merupakan fokus utama dalam pembutan sistem ini. Sistem pendukung keputusan tersebut akan dibangun dan dikombinasi antara metode Fuzzy Analytical Hierarchy Process (Fuzzy AHP) dan Technique For Order Preference By Similarity To Ideal Solution (TOPSIS). Penentuan kriteria dan pembobotan kriteria dilakukan dengan berdasar pada pendapat ahli yang masuk ke sistem menggunakan metode supervised. Nilai hasil uji atlet didapat dari uji tanding dan non-tanding. Penelitian ini diharapkan mampu memberikan rekomendasi atlet panahan yang lolos seleksi dengan akurasi tinggi. Dengan memakai kriteria dari ahli dan juga sistem seleksi uji tanding yang sudah ada diharapkan sistem lebih dapat membantu pengguna.

\subsection{Analisis Kebutuhan Sistem}

Dalam proses pembangunan sistem peneliti harus dapat membantu pengguna dengan sistem pendukung keputusan seleksi atlet panahan menggunakan metode Fuzzy AHP-TOPSIS, berikut yang harus terpenuhi oleh sistem.

1. Sistem harus mendapat kriteria, subkriteria, nilai kriteria dan bobot awal subkriteria dari ahli yang dimasukkan ke dalam sistem dalam penelitian ini peneliti menggunakan kriteria berpasangan yang di isi oleh ahli. 
2. Sistem harus mampu melakukan perhitungan metode Fuzzy AHP untuk menentukan bobot kriteria dan bobot subkriteria yang sesuai dengan menggunakan kriteria, subkriteria, nilai kriteria dan bobot awal subkriteria yang didapat dari ahli pada proses sebelumnya.

3. Sistem harus mampu melakukan perhitungan dengan metode TOPSIS dengan masuk dari pengguna berupa nilai atlet yang kemudian menghasilkan nilai preferensi yang dapat digunakan dalam proses perangkingan maupun penyeleksian setelahnya.

\subsection{Penentuan Kriteria dan Pembobotan}

Dalam penentuan kriteria ini, dilakukan studi literatur terhadap buku-buku maupun jurnaljurnal penelitian ilmu keolahragaan, khususnya panahan tentang penentuan norma dan instrumen penelitian dalam menguji kemampuan seorang atlet panahan. Norma dan instrumen tersebut yang nantinya akan digunakan untuk mendapatkan data kemampuan tiap atlet dengan malakukan pengujian tanding dan non-tanding secara langsung. Norma dan instrumen itulah yang akan dipakai sebagai kriteria dalam sistem pendukung keputusan ini. hal ini selanjutnya kerangka konseptual penelitian kriteria penilaian atlet panahan digambarkan sebagai berikut:

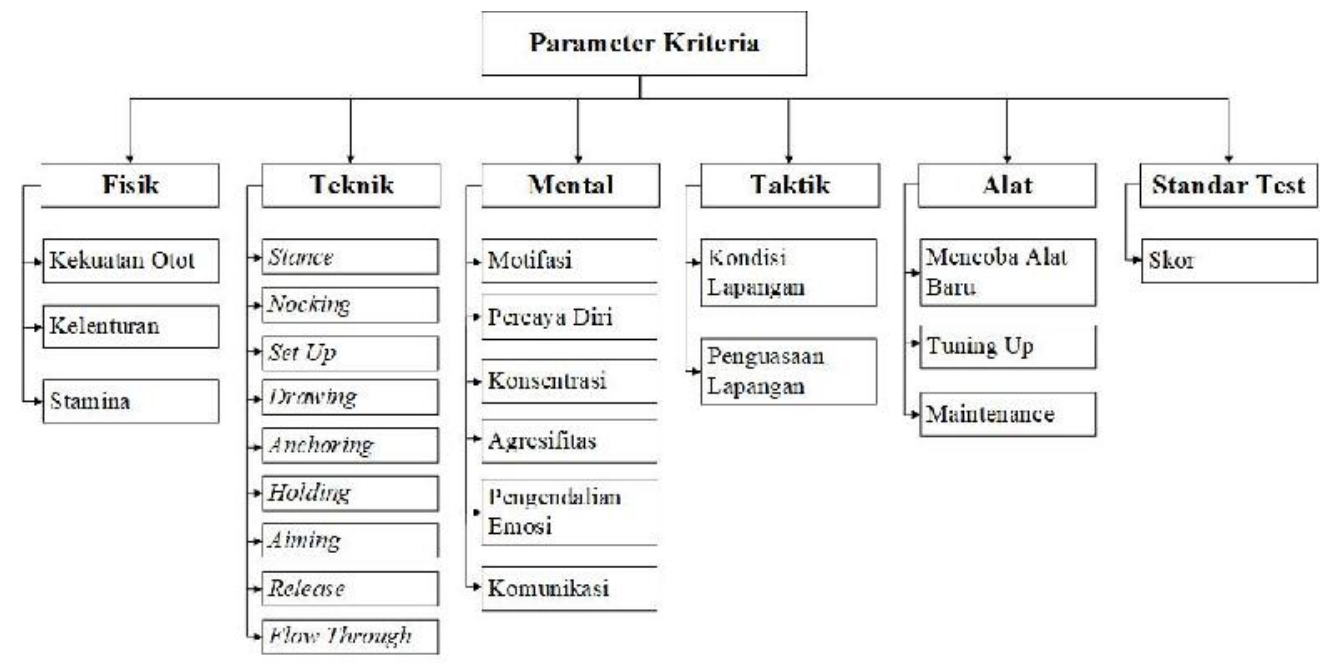

Gambar 3.1 Diagram Kerangka Konsep Kriteria Penilaian

\subsection{Flowchart}

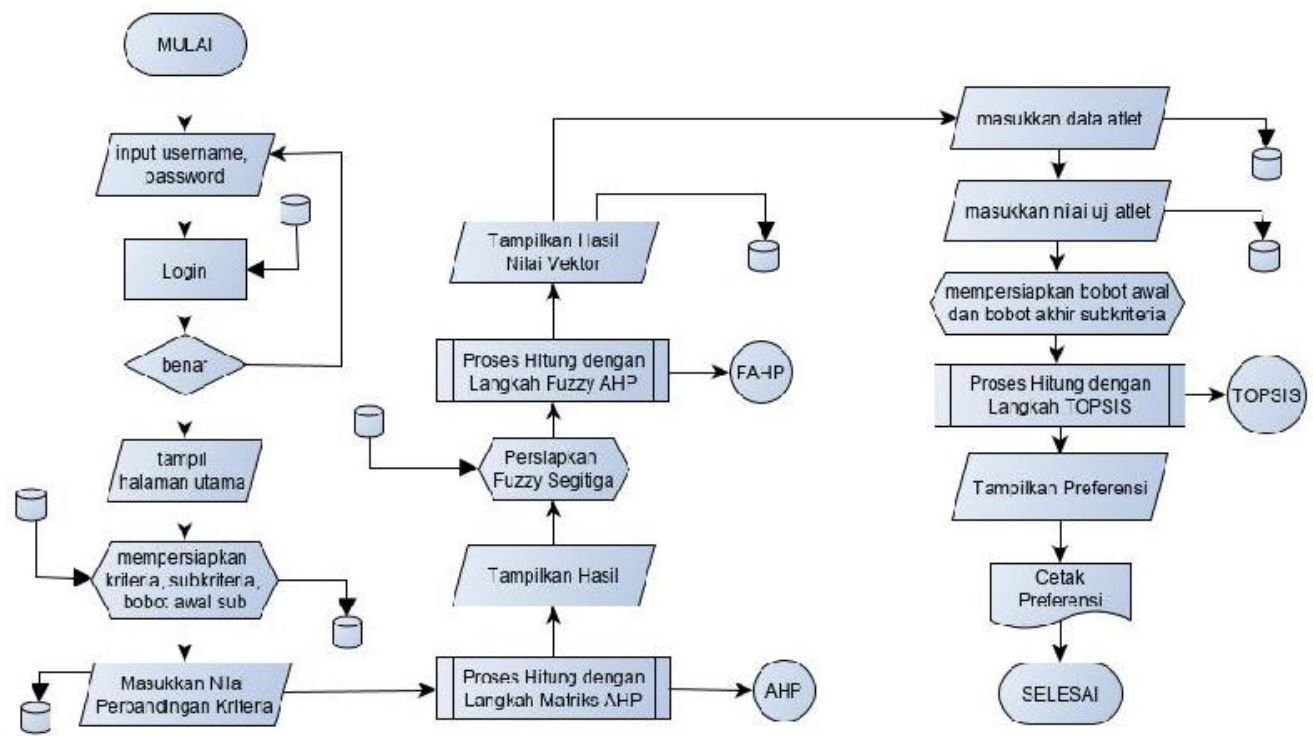

Gambar 3.2 Flowchart SPK seleksi atlet 

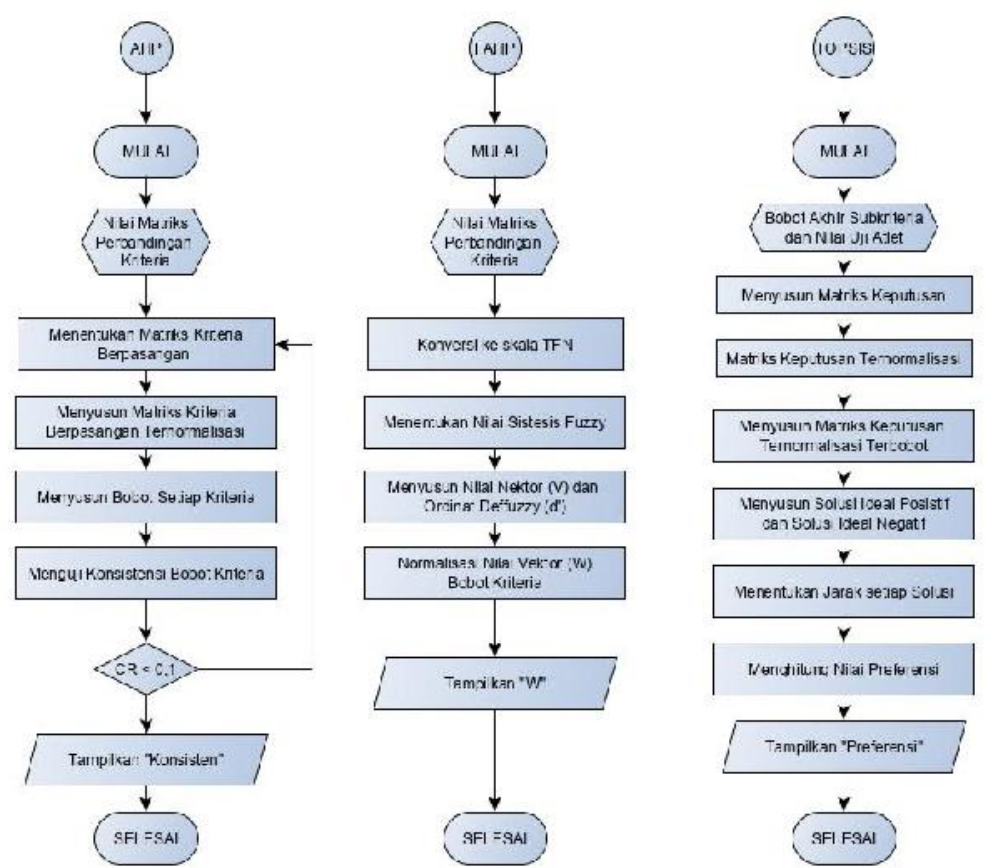

Gambar 3.3 Flowchart Proses Detail Perhitungan Seleksi Atlet

\subsection{Context Diagram}

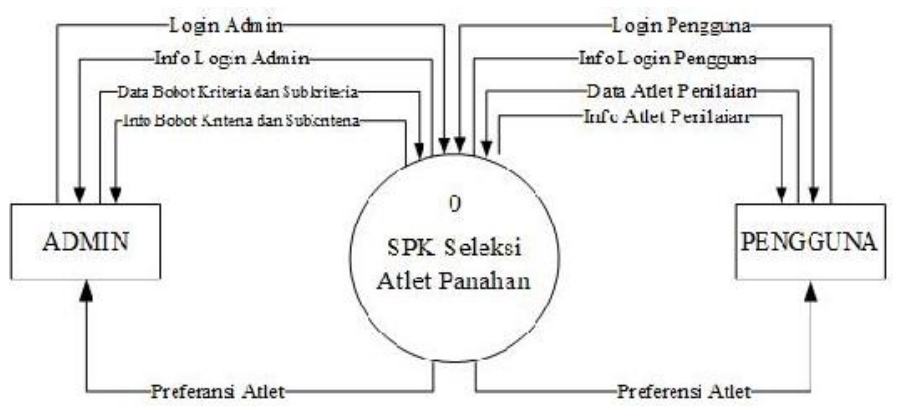

Gambar 3.4 Context Diagram SPK seleksi atlet panahan.

\subsection{Data Flow Diagram (DFD) level 0}

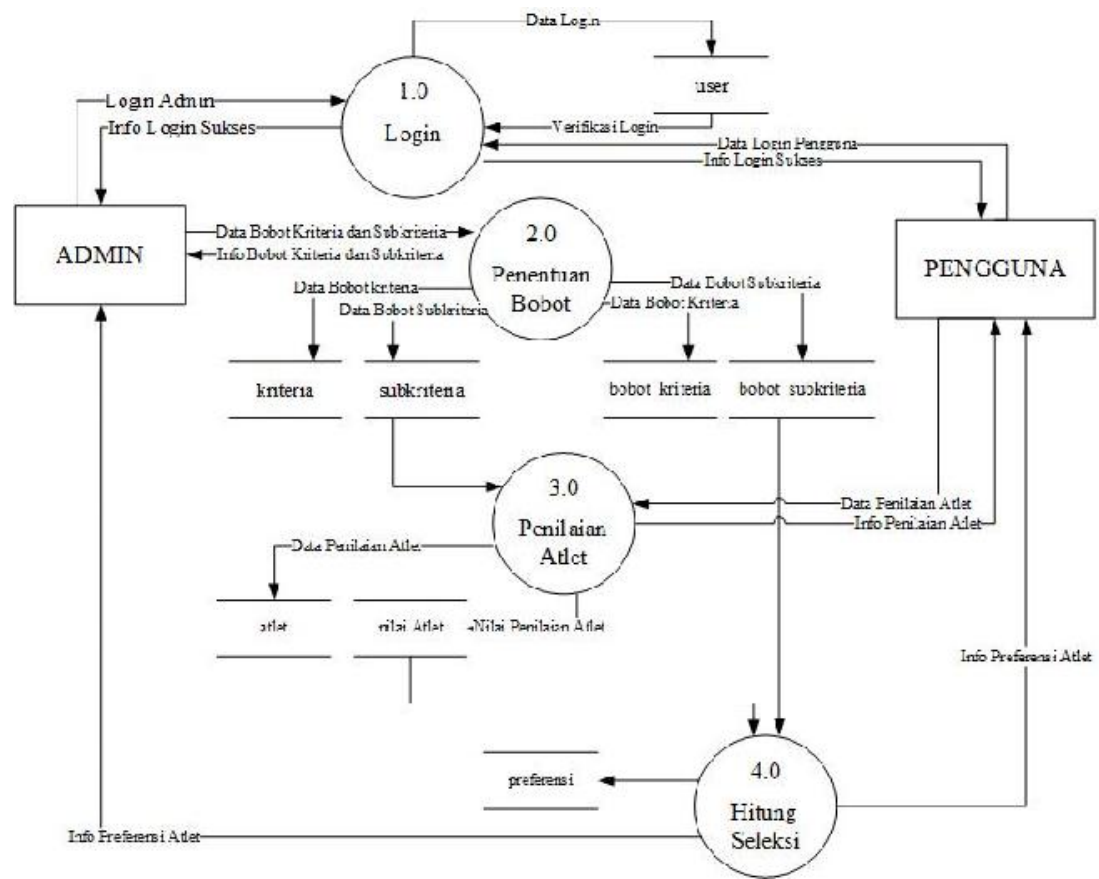

Gambar 3.5 Data Flow Diagram level 0 


\subsection{ERD}

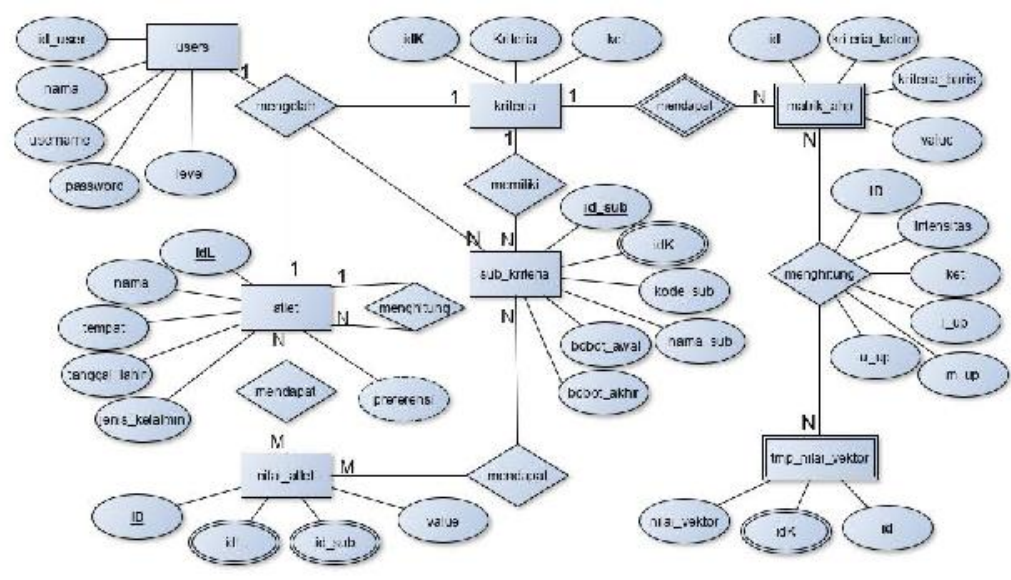

Gambar 3.6 ERD SPK Seleksi Atlet Panahan

\subsection{Desain Tabel}

\subsubsection{Tabel Login}

\begin{tabular}{|l|c|c|c|}
\multicolumn{1}{|c|}{ Tabel 3.1 Tabel User } \\
\hline Name & Type & $\begin{array}{c}\text { Panjang } \\
\text { Field }\end{array}$ & Keterangan \\
\hline id_user & int & & Primary key \\
\hline Nama & varchar & 20 & \\
\hline Username & varchar & 20 & \\
\hline Password & varchar & 100 & \\
\hline Level & int & & \\
\hline
\end{tabular}

\subsubsection{Tabel Kriteria}

Tabel 3.2 Tabel Kriteria

\begin{tabular}{|l|c|c|l|}
\hline \multicolumn{1}{|c|}{ Name } & Type & $\begin{array}{c}\text { Panjang } \\
\text { Field }\end{array}$ & Keterangan \\
\hline idK & Int & & Primary key \\
\hline Kriteria & varchar & 6 & \\
\hline ket & varchar & 100 & \\
\hline
\end{tabular}

\subsubsection{Tabel Kriteria Berpasangan}

Tabel 3.3 Tabel Kriteria Berpasangan

\begin{tabular}{|l|c|c|c|}
\hline \multicolumn{1}{|c|}{ Name } & Type & $\begin{array}{c}\text { Panjang } \\
\text { Field }\end{array}$ & Keterangan \\
\hline ID & Int & & Primary key \\
\hline kriteria_kolom & float & & \\
\hline kriteria_baris & float & & \\
\hline value & float & & \\
\hline
\end{tabular}

\subsubsection{Tabel Fuzzy AHP}

Tabel 3.4 Tabel Fuzzy AHP

\begin{tabular}{|l|c|c|c|}
\hline \multicolumn{1}{|c|}{ Name } & Type & $\begin{array}{c}\text { Panjang } \\
\text { Field }\end{array}$ & Keterangan \\
\hline id & Int & & Primary key \\
\hline $\begin{array}{l}\text { inten- } \\
\text { sitas }\end{array}$ & float & & \\
\hline ket & text & & \\
\hline 1_up & float & & \\
\hline m_up & float & & \\
\hline u_up & float & & \\
\hline
\end{tabular}




\subsubsection{Tabel Nilai Vektor}

Tabel 3.5 Tabel Nilai Vektor

\begin{tabular}{|l|c|c|l|}
\hline \multicolumn{1}{|c|}{ Name } & Type & $\begin{array}{c}\text { Panjang } \\
\text { Field }\end{array}$ & Keterangan \\
\hline Id & int & & Primary key \\
\hline idK & int & 6 & Foreign key \\
\hline $\begin{array}{l}\text { nilai_vekt } \\
\text { or }\end{array}$ & float & 100 & \\
\hline
\end{tabular}

\subsubsection{Tabel subkriteria}

Tabel 3.6 Tabel subkriteria

\begin{tabular}{|l|c|c|l|}
\hline \multicolumn{1}{|c|}{ Name } & Type & $\begin{array}{c}\text { Panjang } \\
\text { Field }\end{array}$ & Keterangan \\
\hline id_sub & int & & Primary key \\
\hline idK & int & & Foreign key \\
\hline kode_sub & varchar & 25 & \\
\hline nama_sub & varchar & 25 & \\
\hline bobot_awal & float & & \\
\hline bobot_akhir & float & & \\
\hline
\end{tabular}

\subsubsection{Tabel Atlet}

Tabel 3.7 Tabel Atlet

\begin{tabular}{|l|c|c|c|}
\hline \multicolumn{1}{|c|}{ Name } & Type & $\begin{array}{c}\text { Panjang } \\
\text { Field }\end{array}$ & Keterangan \\
\hline idL & int & & Primary key \\
\hline Nama & varchar & 20 & \\
\hline Tempat & varchar & 15 & \\
\hline $\begin{array}{l}\text { tang- } \\
\text { gal_lahir }\end{array}$ & date & 1 & \\
\hline $\begin{array}{l}\text { jenis_kelam } \\
\text { in }\end{array}$ & varchar & 1 & \\
\hline
\end{tabular}

\subsubsection{Tabel Nilai Atlet}

Tabel 3.7 Tabel Nilai Atlet

\begin{tabular}{|l|c|c|l|}
\hline \multicolumn{1}{|c|}{ Name } & Type & $\begin{array}{c}\text { Panjang } \\
\text { Field }\end{array}$ & Keterangan \\
\hline ID & Int & & Primary key \\
\hline idL & Int & 10 & Foreign key \\
\hline id_sub & Int & 10 & \\
\hline ilai & Int & 10 & \\
\hline
\end{tabular}

\subsection{Relasi Basis Data}
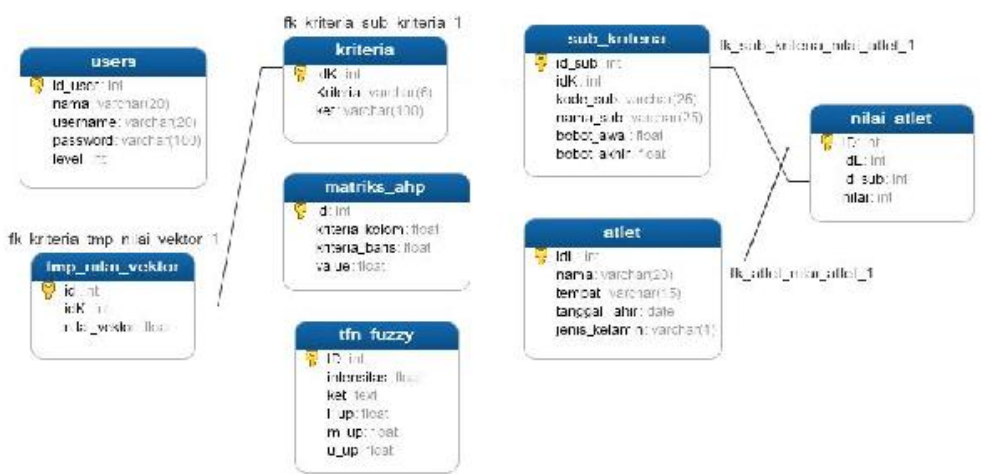

Gambar 3.4 Relasi Basis Data 


\section{Implementasi dan Pembahasan}

\subsection{Form Login}

Form login digunakan admin dan kepala sekolah untuk memasukkan password dan username untuk bisa masuk ke halaman utama admin dan kepala sekolah. Berikut adalah tampilan form login :

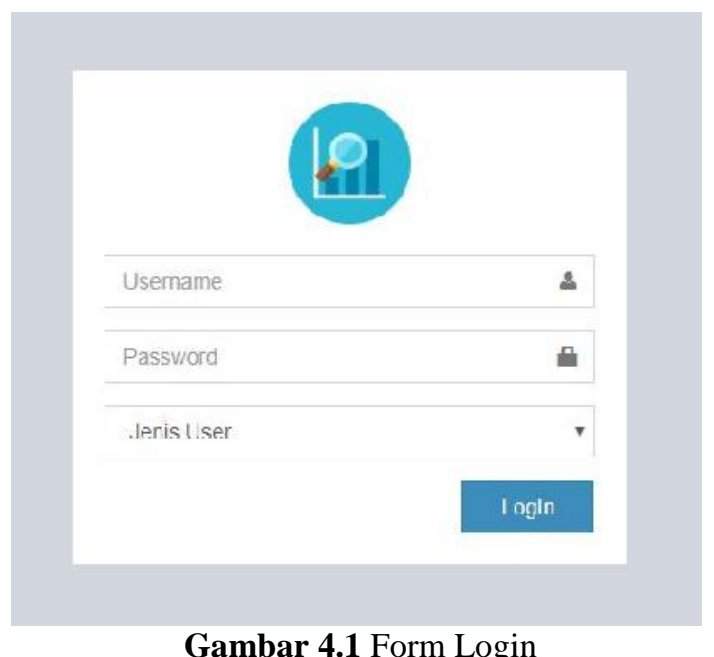

\subsection{Form Halaman Utama}

Form halaman utama merupakan halaman yang akan ditampilkan pertama jika berhasil login. Halaman utama berbeda-beda sesuai dengan level akun. Berikut ini masing masing level akun.

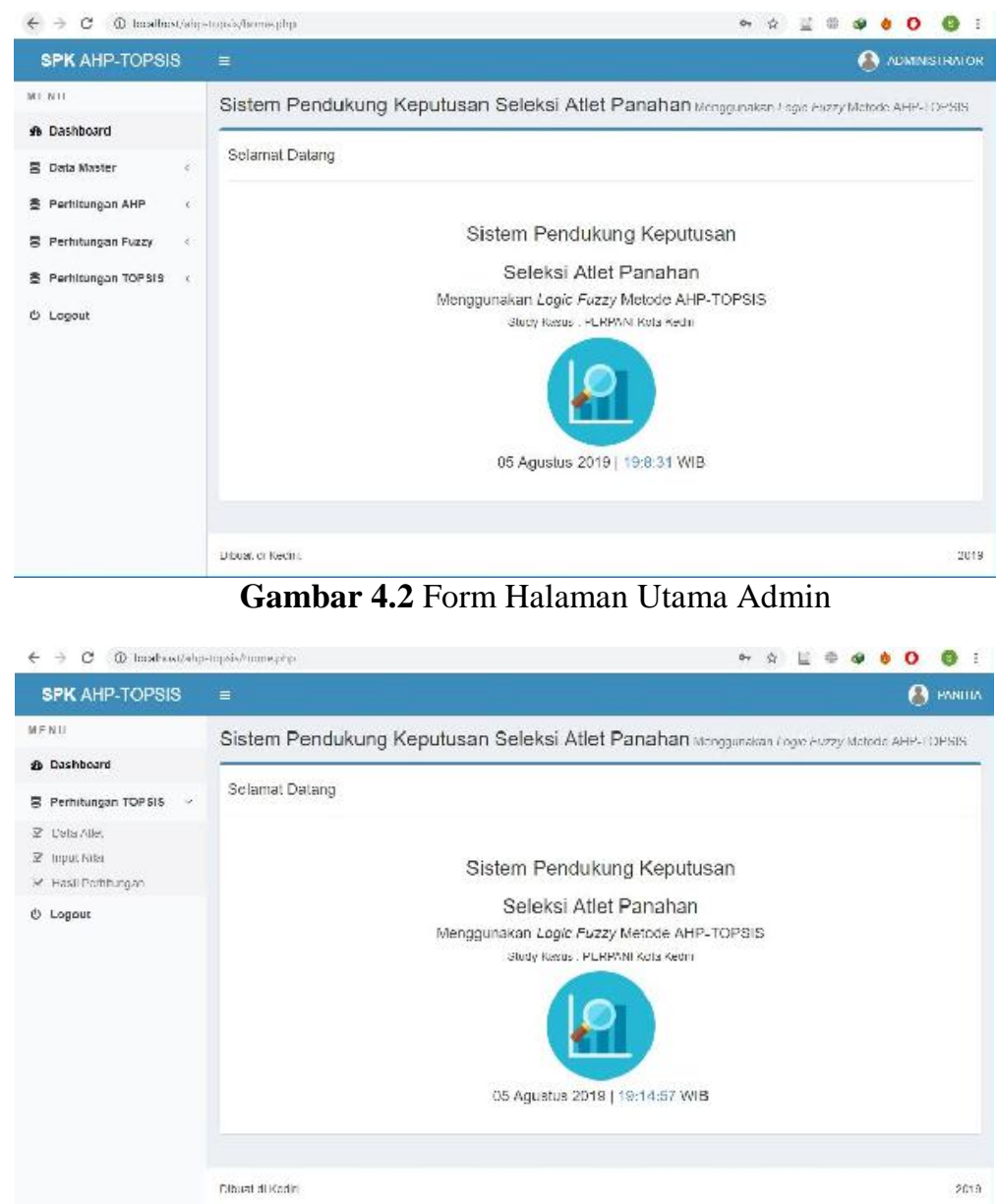

Gambar 4.3 Form Halaman Utama Panitia 


\subsection{Form Kriteria}

Terdapat 6 kriteria yang menjadi bahan pertimbangan sistem ini, antara lain Fisik, Teknik, Mental, Taktik, Alat dan Standar Tes.

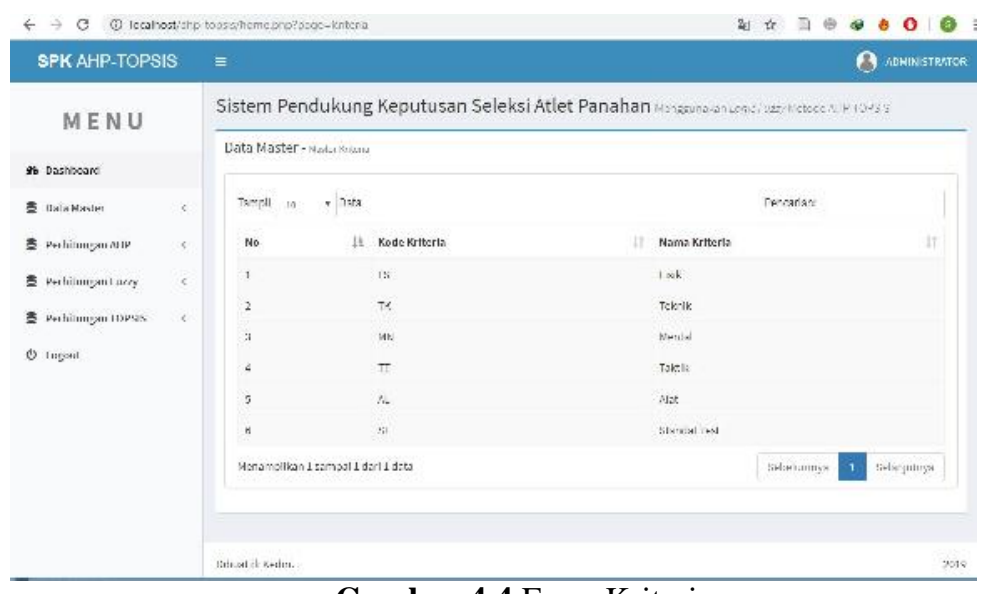

Gambar 4.4 Form Kriteria

\subsection{Form Data Atlet}

Memasukkan data atlet dilakukan oleh panitia melalui menu. Data yang perlu dimasukkan adalah nama, jenis kelamin, tempat lahir, tanggal lahir dan alamat. Form data atlet berikut ini penjelasannya.

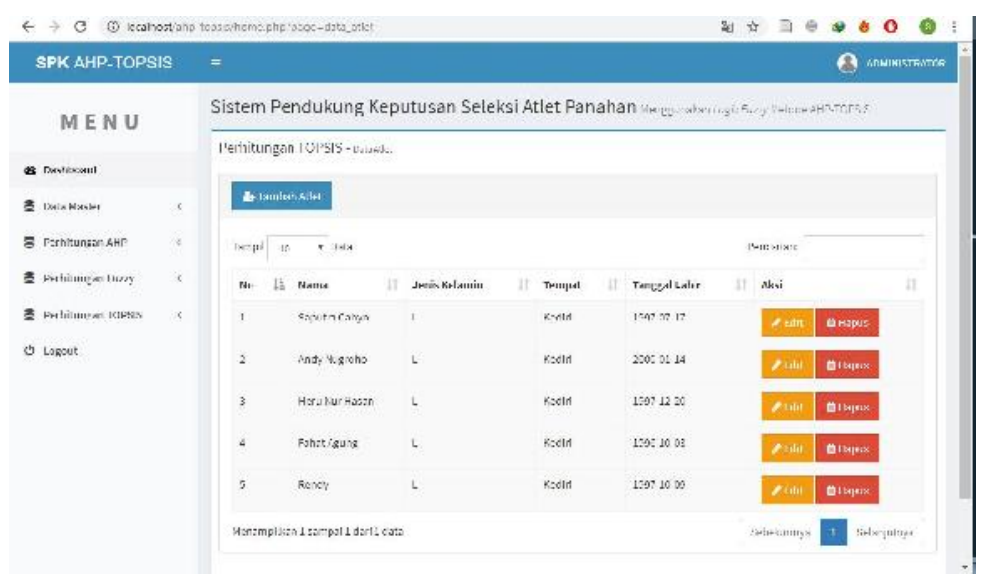

Gambar 4.5 Form Data atlet

\subsection{Form Tambah Data Atlet}

Menambah data atlet dilakukan setelah mengeklik tombol tambah atlet. Dalam hal ini menggunakan fungsi modal yaitu muncul kotak dialog baru untuk tambah data. Data yang perlu dimasukkan adalah nama, jenis kelamin, tempat lahir dan tanggal lahir. Form tambah data atlet dilihat pada gambar berikut.

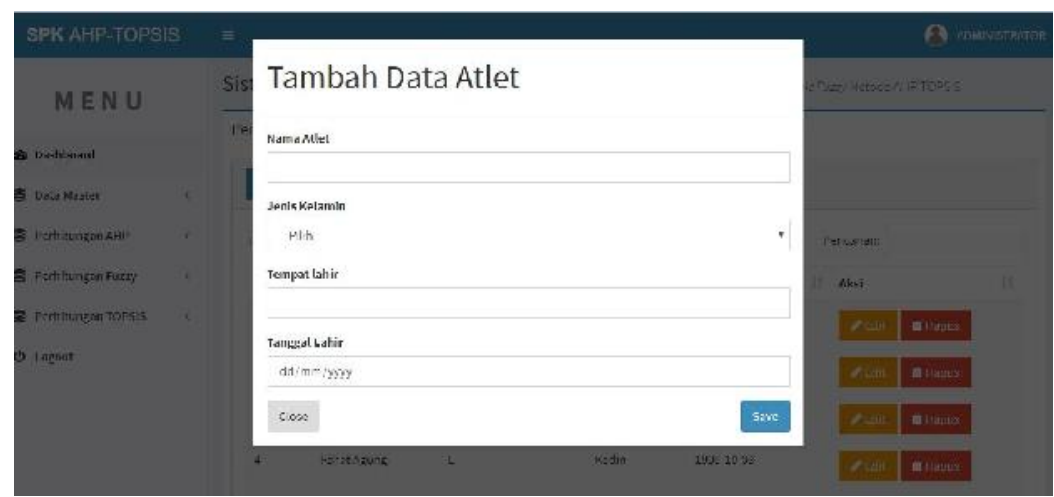

Gambar 4.6 Form Tambah Data atlet 


\subsection{Form Input Nilai Atlet}

Form input nilai atlet adalah memasukkan seluruh nilai uji tes subkriteria terhadap masingmasing atlet. Form input nilai atlet digambarkan sebagai berikut.

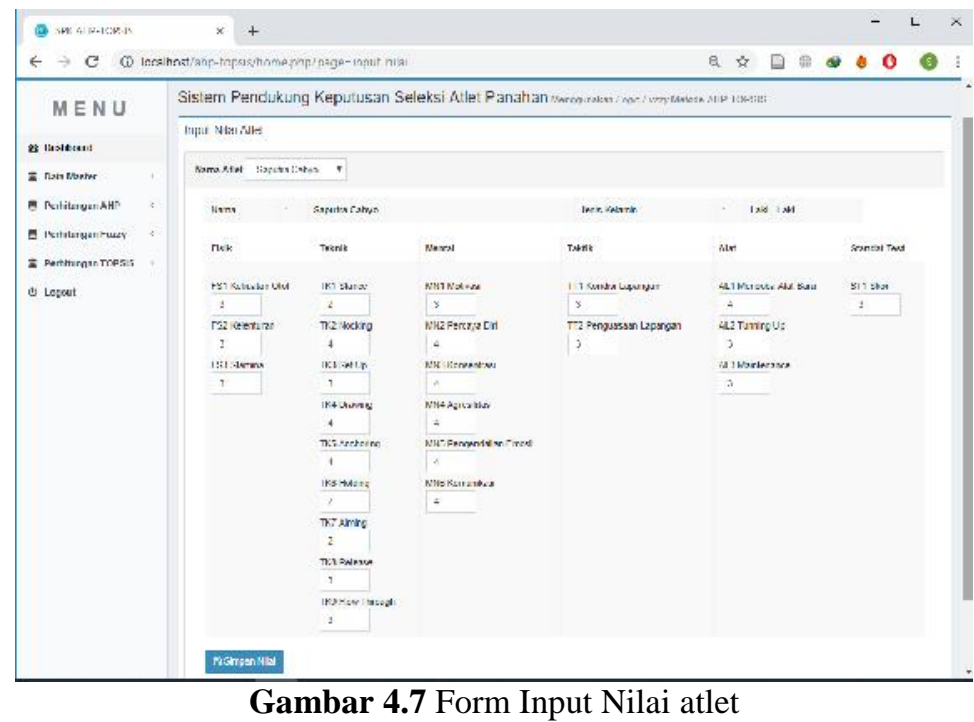

\subsection{Hasil Preferensi}

Hasil akhir nilai preferensi atlet ditampilkan melalui peringkat. Pada tahap akhir pengujian sistem menampilkan peringkat atlet terbaik dengan nilai preferensi tertinggi. Digambarkan dalam sistem sebagai berikut.

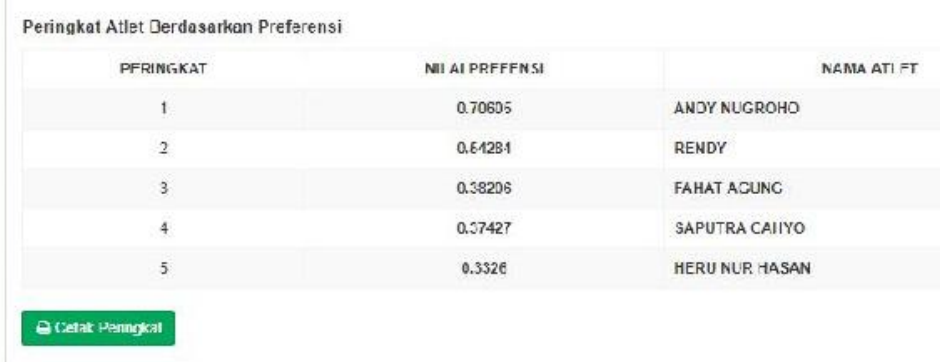

Gambar 4.8 Pengujian Peringakat Atlet Terhadap Preferensi

\section{Kesimpulan dan Saran}

\subsection{Kesimpulan}

Berdasarkan pembahasan implementasi dan evaluasi dari bab-bab sebelumnya serta teori yang ada, diambil kesimpulan sebagai berikut:

a. Dalam penelitian ini menerapkan metode Fuzzy AHP untuk menentukan konsistensi bobot kriteria. Dari hasil pengujian, dapat disimpulkan bahwa pembobotan 6 kriteria yang didapat dari observasi di PERPANI nilai bobot kriteria dihasilkan menggunakan perhitungan FAHP.

b. Penelitian ini berhasil menerapkan metode Fuzzy AHP dan TOPSIS dalam sistem pendukung keputusan seleksi atlet. Dalam merangking 5 subjek penelitian dalam seleksi atlet.

c. Dari penggabungan metode AHP dan TOPSIS dapat dikatakan bahwa dengan cara penggabungan kedua metode lebih akurat efisien karena pembuktian hasil perangkingan penelitian dengan matematis. 


\subsection{Saran}

Bagi peneliti yang memilih judul sejenis hendaknya:

a. Melakukan analisis lebih lanjut terhadap penentuan batasan dari setiap metode AHP dan TOPSIS.

b. Malakukan analisis penilaian lebih lanjut ketingkat cabang olahraga lainnya.

c. Mengembangkan program ini secara online sehingga dapat mengambil hasil keputusan dimanapun berada dan dapat digunakan untuk Lembaga lain dalam menentukan seleksi atlet.

\section{Daftar Pustaka}

[1] Afifah, Insan. (2018). Sistem Pendukung Keputusan Rekomendasi Kenaikan Jabatan Dosen UIN Maulana Malik Ibrahim Malang Dengan Metode Fuzzy AHP. Skripsi. Fakultas Sains dan Teknologi UIN Maulana Malik Ibrahim. Malang

[2] Afrianty, Iis. (2011). Sistem Pendukung Keputusan (SPK) Pemilihan Karyawan Terbaik Menggunakan Metode Fuzzy AHP (F-AHP). Skripsi. Fakultas Sains dan Teknologi UIN Sultan Syarif Kasim. Riau

[3] Chang, D. Y. (1996) Applications of the extent analysis method on fuzzy AHP. European Journal of Operational Reseach, 95(3), 649-655. https://doi.org/10.1016/03772217(95)00300-2

[4] Hakim, Husnul, dkk. (2018). Seleksi Penelusuran Minat Dan Kemampuan (PMDK) Dengan Fuzzy Topsis. Jurnal Ilmiah Teknologi Informasi - Volume 16, Nomor 2: 134 - 143

[5] Kusrini. (2007). Konsep dan Aplikasi Sistem Pendukung Keputusan. Yogyakarta: Penerbit Andi.

[6] Mukhtar, dkk. (2017). Hubungan Tingkat Konsentrasi Dengan Ketepatan Memanah Pada Atlet Panahan Aceh Archery School Binaan Dispora Kabupaten Bireuen Tahun 2015. Jurnal Ilmiah Mahasiswa Pendidikan Jasmani, Kesehatan dan Rekreasi Fakultas Keguruan dan Ilmu Pendidikan Unsyiah Volume 3, Nomor 1: 9 - 14

[7] Saaty, T. L. (1995). Decision Making for Leaders: The Analytical Hierarchy Process for Decisions in a Complex World, Rev. ed. Pittsburgh: RWS Publishers

[8] Sugiyono. (2014). Metode Penelitian Kuantitatif, Kualitatif, dan R\&D. Bandung: Penerbit Alfabeta

[9] Turban, E. (2005). Decission Support Systems and Intelligent Systems Edisi Bahasa Indonesia Jilid 1. Andi. Yogyakarta

[10] S. W. Mudjanarko, S. Winardi, and A. D. Limantara, "Pemanfaatan internet of things (iot) sebagai solusi manejemen transportasi kendaraan sepeda motor," Pros. Semin. Nas. Apl. Teknol. Prasarana Wil. X, no. August, 2017.

[11] A. D. Triono et al., "Utilization of Pedestrian Movement on the Sidewalk as a Source of Electric Power for Lighting Using Piezoelectric Censors," in 2018 3rd IEEE International Conference on Intelligent Transportation Engineering, ICITE 2018, 2018.

[12] A. D. Limantara, L. D. Krisnawati, S. Winardi, and S. W. Mudjanarko, "Solusi Pengawasan Kebijakan Mengatasi Kemacetan Jalan dan Parkir Kota Berbasis Internet Cerdas," Semin. Nas. Teknol. dan Rekayasa Inf., no. November, pp. 1-6, 2017.

[13] A. D. Limantara, S. Winarto, and S. W. Mudjanarko, "Sistem Pakar Pemilihan Model Perbaikan Perkerasan Lentur berdasarkan Indeks Kondisi Perkerasan (Pci)," Semin. Nas. dan Teknol. Fak. Tek. Universtas Muhammadiyah Surakarta, no. November, pp. 1-2, 2017.

[14] A. D. Limantara, Y. Cahyo, S. Purnomo, and S. W. Mudjanarko, "Pemodelan Sistem Pelacakan LOT Parkir Kosong Berbasis Sensor Ultrasonic Dan Internet Of Things ( IOT ) Pada Lahan Parkir Diluar Jalan," Semin. Nas. Sains dan Teknol., vol. 1, no. 2, pp. 1-10, 2017.

[15] A. Alimudin, A. Z. Falani, S. W. Mudjanarko, and A. D. Limantara, "Analisis Pengaruh Penerapan Perspektif Balanced Scorecard Terhadap Peningkatan Kinerja UMKM,” Ekonika J. Ekon. Univ. kadiri, vol. 4, no. 1, p. 1, 2019. 